\title{
Surface of AISI 316 as Electrode Material for Water Electrolysis Under Potassium Hydroxide for Hybrid Car Application
}

\section{Ida Hamidah ${ }^{1 *}$, Agus Solehudin ${ }^{1}$, Agus Setiawan ${ }^{1}$, Lilik Hasanah$^{2}$, Budi Mulyanti ${ }^{3}$, Asep Bayu Dani Nandiyanto ${ }^{4}$ and Khairurrijal Khairurrijal ${ }^{5}$}

\author{
${ }^{1}$ Department of Mechanical Engineering Education, Universitas Pendidikan Indonesia, \\ Jl. Dr. Setiabudi no 229 Bandung 40154, Indonesia \\ *Email: idahamidah@upi.edu \\ Phone: +62 22 2002007; Fax: +62 222002007 \\ ${ }^{2}$ Department of Physics Education, Universitas Pendidikan Indonesia, \\ Jl. Dr. Setiabudi no 229 Bandung 40154, Indonesia \\ ${ }^{3}$ Department of Electrical Engineering Education, Universitas Pendidikan Indonesia, \\ Jl. Dr. Setiabudi no 229 Bandung 40154, Indonesia \\ ${ }^{4}$ Departemen Kimia, Universitas Pendidikan Indonesia, \\ Jl. Dr. Setiabudi no 229 Bandung 40154, Indonesia \\ ${ }^{5}$ Department of Physics, Institut Teknologi Bandung, \\ Jl. Ganesha no. 10 Bandung 40132, Indonesia
}

\begin{abstract}
This study is to evaluate the surface of AISI 316 as an electrode material for water electrolysis under various potassium hydroxide $(\mathrm{KOH})$ electrolyte concentrations. In the experimental method, AIS316 electrode and $\mathrm{KOH}$ solution put into the water electrolysis system. The electrolysis system was combined with the hybrid car engine system that consumed a combination of hydrogen and gasoline as the fuel source. $\mathrm{KOH}$ solution concentration was varied from 0 to $0.53 \mathrm{M}$, which was then used to evaluate the surface of AISI 316 electrode as well as hybrid car performances. The experimental results showed that electrolyte solution concentration is an important parameter to maintain highefficiency hydrogen generation. The more $\mathrm{KOH}$ added it gave benefits for creating the more hydrogen gas. However, it brought problems in the electrode surface corrosion. The optimum condition to get more hydrogen gas but with less corrosion damage was obtained when performing the process with $0.40 \mathrm{M}$ of $\mathrm{KOH}$. Indeed, the result also found that the more hydrogen gas being produced has a direct correlation to the reduction of fuel consumption and exhaust gas emission (e.g., $\mathrm{CO}_{2}, \mathrm{CO}$, and $\mathrm{NO}_{\mathrm{x}}$ ).
\end{abstract}

Keywords: Potassium hydroxide; AISI 316; corrosion resistance; fuel savings; exhaust gas emission reduction.

\section{INTRODUCTION}

Recently, studies on the water electrolysis for hydrogen production have attracted tremendous attention for researchers. Water electrolysis is very simple as the process can be done in a one-pot apparatus system, known as a water electrolyser. The hydrogen is generated by involving the reaction of the metallic electrode in the electrolyte (either acid or basic solution) under the introduction of the voltage source [1].

To improve the efficiency of the water electrolyser, several strategies have been proposed, including additional layers of proton exchange membrane [2, 3], manufacturing 
multilayer cell electrode structure [4], selecting excellent electrode material $[5,6]$, and bringing several choices for electrolyte solution [6, 7]. Although their reports are welldocumented, there is no research on the investigation onto corrosion resistance of the surface of the electrode. Further, their researches limited to the production of hydrogen gas only and no information about the possible direct application of hydrogen gas.

Based on our previous studies [8,9], the purpose of this study was to evaluate the surface of AISI 316 as the electrode material for water electrolysis under various potassium hydroxide $(\mathrm{KOH})$ electrolyte concentrations. AISI 316 was used as a model of electrode since this material has been well-known and categorised as one of the best electrode materials for generating hydrogen based on our previous report [8].

The AISI 316 electrode and $\mathrm{KOH}$ solution were placed in the water electrolysis system. Different from other reports regarding the water electrolysis apparatus [1], the present electrolysis system was combined with the hybrid car engine system. The hybrid car engine system consumed a combination of hydrogen and gasoline as the fuel source. $\mathrm{KOH}$ solution concentration was varied from 0 to $0.53 \mathrm{M}$, which was then used to evaluate the surface of AISI 316 electrode as well as hybrid car performances.

\section{METHODOLOGY}

\section{Materials}

This study used $\mathrm{KOH}$ (Bratachem, Indonesia) and AISI 316. KOH was used directly without further purification process. For preparing the electrolyte solution, $\mathrm{KOH}$ was diluted into aqueous solution directly. Various $\mathrm{KOH}$ concentrations were tested from 0 to $0.53 \mathrm{M}$.

\section{Apparatus for Water Electrolysis}

In the experimental procedure, AISI 316 and $\mathrm{KOH}$ electrolyte solution were placed into the water electrolysis system (Figure 1). The system apparatus was equipped with a hybrid car engine system. The system consisted of $300 \mathrm{~mL}$ glass reactor as the main container as shown in Figure 1 (a) and 300-mL glass reactor as a second container (see container in Figure 1 (b)). The electrolysis process occurs at the main container when electrolyser is connected to the accumulator (see the device in Figure 1(c)). The produced hydroxyl gas (HHO) from electrolysis is then carried out to the second container and finally is flowed to the combustion chamber (see the device in Figure 1 (d)) of the car engine.

The main container consists of a number of negative and positive electrodes and three neutral plates which are inserted in each electrode. The materials of the electrodes are AISI 316. Each electrode is separated by an insulator gasket to inhibit short circuits among them. The second container consists of two cavities. The first cavity (see (b-1) in Figure 1) serves as a chamber to trap the electrolyte solution that is still mixed with_HHO, and the second cavity (see (b-2) in Figure 1) serves as a chamber to condense the residual gas. With the structure of these two cavities, the HHO produced by electrolysis is clean. 


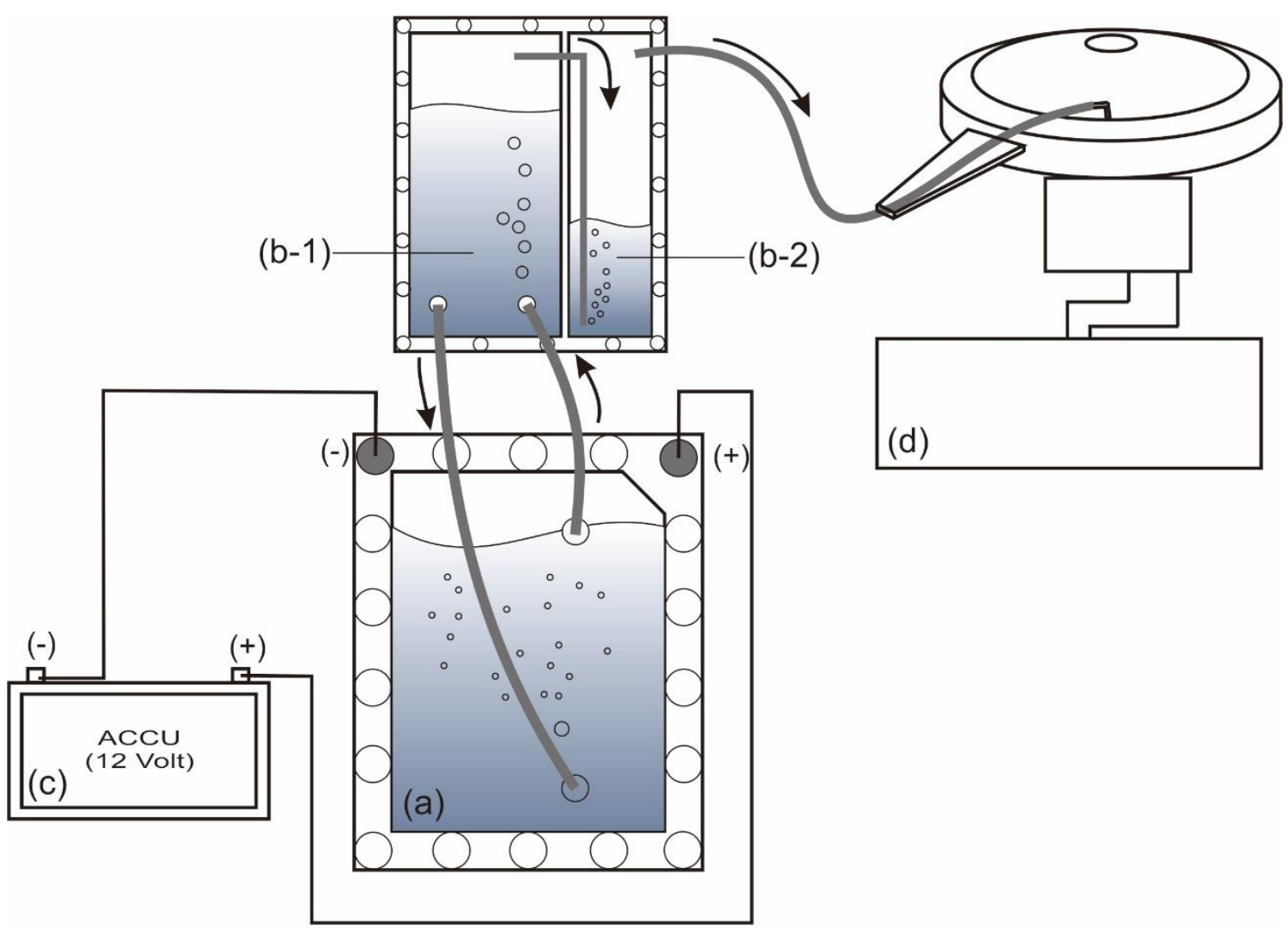

Figure 1. Water electrolysis equipment using AISI 316 as the electrode: (a) main container (contained AISI 316 and $\mathrm{KOH}$ electrolyte), (b) second container, (c) accumulator, and (d) combustion chamber.

\section{Characterisation}

Surface analysis

For surface analysis, characterisations were conducted using a scanning electron microscope (SEM; FE-SEM SU5000, Hitachi Co. Ltd., Japan) that is equipped with an energy dispersive $\mathrm{X}$-ray spectroscopy (EDX).

\section{Mass loss analysis method}

Two characterisation methods were conducted to analyse the performance of water electrolyser, i.e., mass loss analysis method and the constant volume sampling method (CVS). Mass loss analysis method was done to measure the corrosion rate of AISI 316 as the electrode of water electrolyser. The used parameters (i.e., solution concentration, solution temperature, and exposure time) are based on the results of our previous study [8]. In the study, AISI 316 had the most excellent corrosion resistance in $\mathrm{KOH}$ solution of $22.5 \mathrm{gpl}(0.40 \mathrm{M})$ compared to AISI 304 and $\mathrm{Cu}$ alloy. In this case, AISI 316 was dipped in a solution of $\mathrm{KOH}$, sodium hydroxide $(\mathrm{NaOH})$, and sodium chloride $(\mathrm{NaCl})$ for $1344 \mathrm{~h}$ and it was observed for every $336 \mathrm{~h}$. Detail information for the parameters used for testing AISI 316 corrosion resistance is shown in Table 1. 
Table 1. Parameters used in the testing of AISI 316 corrosion resistance in $\mathrm{KOH}$

\begin{tabular}{ll}
\hline Condition & Value \\
\hline Electrolyte concentration & $0.27-0.53 \mathrm{M}$ \\
Temperature & $25^{\circ} \mathrm{C}$ \\
Exposure time & $336-1344 \mathrm{~h}$ \\
\hline
\end{tabular}

\section{Constant volume sampling method}

The performance of the present water electrolyser apparatus was investigated by combining the generated hydrogen with a car engine system (1500 cc of Toyota Kijang $5 \mathrm{~K}$, Toyota Co. Ltd., Japan). The system was tested at various engine rotation speeds and electric currents. The testing parameters are shown in Table 2. The variations of engine rotation speeds and electric currents are intended to obtain the data on fuel savings and reduction of exhaust gas emission.

Table 2. Parameters used in the testing of water electrolyzer performance

\begin{tabular}{ll}
\hline Condition & Value \\
\hline Solution type & KOH $0.00-0.53 \mathrm{M}$ \\
Electric current & $5-15 \mathrm{~A}$ \\
Rotation Speed & $2000-5000 \mathrm{rpm}$ \\
Air Pressure & $960 \mathrm{mbar}$ \\
Air Temperature & $28^{\circ} \mathrm{C}$ \\
Relative humidity & $72 \%$ \\
\hline
\end{tabular}

The analysis on car engine fuel savings was done using CVS method to compare the standard engine fuel consumption (not equipped with electrolyser) and engine fuel consumption equipped by water electrolyser. Electrodes on the water electrolyser were connected with the positive and negative poles of the accumulator, so the electrolyser can work and produce $\mathrm{HHO}$ gas. At the same time, the generated $\mathrm{HHO}$ gas was piped into the engine air filter that is connected directly to the combustion chamber. The addition of HHO gas into the combustion chamber is expected to increase the explosive scale of combustion.

\section{RESULTS AND DISCUSSION}

\section{Surface Analysis Results}

Table 3 shows the surface analysis of AISI 316 under various concentrations of $\mathrm{KOH}$ electrolyte based on corrosion rate. As a standard comparison, the analysis was also done using $\mathrm{NaOH}$ and $\mathrm{NaCl}$ electrolyte solutions. As shown in the table, under constant process condition, the electrolyte types and concentrations play an important role in the corrosion process. The higher concentrations of electrolyte solutions used have correlation to the more production of electrolyte ions. This is due to the more contact and interaction to occur between the ions and the metal electrode that can lead to a corrosion process. 
Table 3. Corrosion rate of AISI 316 using various types and concentrations of electrolyte.

\begin{tabular}{lccc}
\hline & $\mathrm{CR}_{\mathrm{KOH}}(\mathrm{mpy})$ & $\mathrm{CR}_{\mathrm{NaOH}}(\mathrm{mpy})$ & $\mathrm{CR}_{\mathrm{NaCl}}(\mathrm{mpy})$ \\
\hline $0.27 \mathrm{M}$ & 0.012065 & 0.060504 & 0.073505 \\
$0.40 \mathrm{M}$ & 0.018215 & 0.061401 & 0.096779 \\
$0.53 \mathrm{M}$ & 0.115044 & 0.065527 & 0.100382 \\
\hline
\end{tabular}

Regarding the electrolyte types, the lowest and the highest corrosion rates occur in $\mathrm{KOH}$ and $\mathrm{NaCl}$ solution, respectively. Although the chemical properties of $\mathrm{KOH}$, $\mathrm{NaOH}$, and $\mathrm{NaCl}$ are almost similar and are easy to dissolve in water, their activities in the corrosion process are different. For the case of $\mathrm{KOH}$ and $\mathrm{NaOH}$, their activities depend on the hydroxyl $\left(\mathrm{OH}^{-}\right)$ion [10-21]. Their process provides a small amount of $\mathrm{OH}^{-}$ ions, which can give a positive impact to the formation of a protective coating.

In the experiment conducted in $\mathrm{NaCl}$ solution, a higher corrosion rate possibly occurs since chloride $\left(\mathrm{Cl}^{-}\right)$ion is created. This ion is highly active for the corrosion process, and at the same time, it can break the passivity layer created by the $\mathrm{OH}^{-}$ion $[22$, 23]. Further, with the addition of $\mathrm{NaCl}$ concentration of up to $0.53 \mathrm{M}$, the conductivity of the solution increases. The increase in the conductivity of the solution is proportional to the increase in the corrosion current density and relates to the creation of high solubility of $\mathrm{O}_{2}$ as an oxidant.

As shown in Table 3, AISI 316 in all types and concentrations of the electrolytes has the highest corrosion rate of 0.115044 mpy. This means that the AISI 316 is highly resistant to the environment that influences electrolyte solution [24-26]. As a consequence, AISI 316 was used as an electrode material in water electrolyser. In addition, since $\mathrm{KOH}$ is an alkaline solution and has less corrosion damage to AISI 316, $\mathrm{KOH}$ with various concentrations was used as a main electrolyte solution in the water electrolyser.

Figure 2 shows the SEM images of the AISI 316 surface before and after dipping into the KOH solution. As shown in Figure 2(a), the structure of AISI 316 is relatively smooth. Then, after put into the $\mathrm{KOH}$ solution after several hours, the corrosion process occurs, resulting in some cavities and holes as shown by the red mark in Figure 2(b). This result confirms for the occurrence of the corrosion process.

Based on the results of the SEM analysis in Figure 2, the corrosion type of AISI 316 was pitting corrosion. This occurred when an oxide layer on the surface of AISI 316 was damaged by aggressive chemical species, such as $\mathrm{Cl}^{-}$and $\mathrm{H}^{+}$ions. The corrosion can be prevented if the electrode has time for immediate re-passivation. Pitting corrosion is a common type of corrosion. This occurs in a material that is exposed to the acid/base environment. When it happens as the result of the metal anode system, this type of corrosion is extremely dangerous. The corrosion process is invisible and can continue even though the only visible parts on the surface are small holes. This corrosion mechanism occurs because of a physical or metallurgical influence (their carbide precipitation or inclusion). In addition, there is one area on the metal surface that is corroded faster than the others. These conditions gave rise to a small pit, and rapid metal dissolution occurred in the pit when the oxygen reduction occurred on a flat surface. Fast dissolving metal will result in the displacement of ions. Another study also showed that pitting corrosion is contributed by the elastic zone stress under the yield strength of the material in cases when immersion and stress are applied simultaneously [19]. 

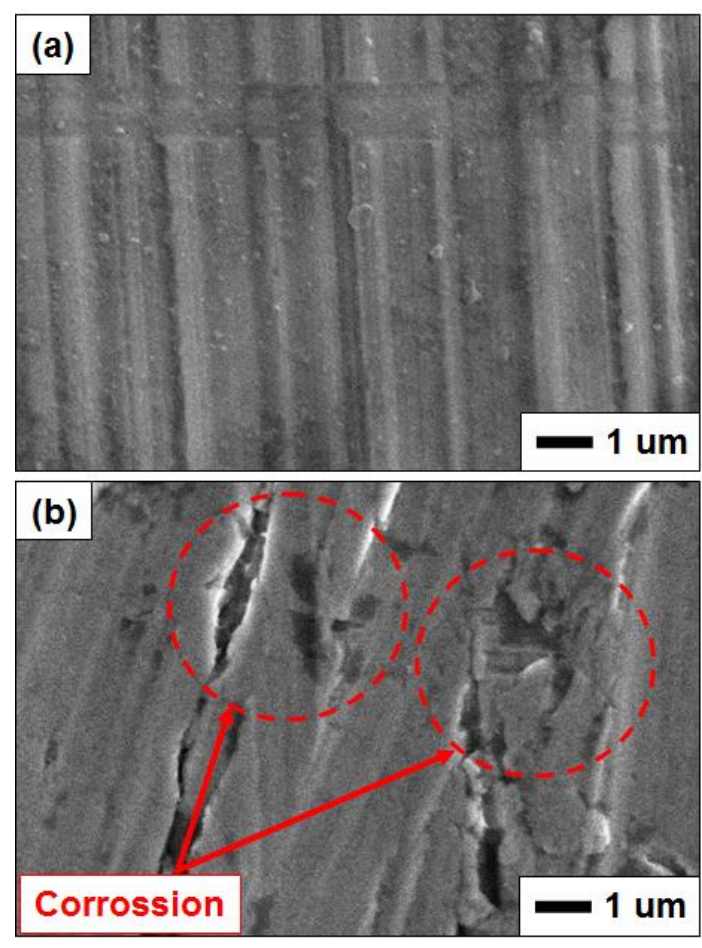

Figure 2. SEM images of AISI 316 before (a) and after (b) the dipping process in $\mathrm{KOH}$ solution.

Table 4 shows the EDS result of the AISI 316 before and after the corrosion process using the $\mathrm{KOH}$ solution. As shown in the table, the composition of some elements has changed during the corrosion process. Iron, chromium, and nickel composition decreased, which was due to the corrosion process. The elements were removed from the mother material and dissolved into the solution.

Table 4. Elemental composition of AISI 316 before and after the corrosion process using $\mathrm{KOH}$ solution.

\begin{tabular}{lcc}
\hline \multirow{2}{*}{ Element } & \multicolumn{2}{c}{ Elemental composition (wt. \%) } \\
\cline { 2 - 3 } & Before corrosion* & After corrosion \\
\hline $\mathrm{C}$ & 0.08 & 4.69 \\
$\mathrm{Cr}$ & 19.00 & 13.34 \\
$\mathrm{Ni}$ & 12.00 & 6.36 \\
$\mathrm{Fe}$ & 68.40 & 51.24 \\
\hline
\end{tabular}

Note: *taken from references[8, 27]

To ensure the main reason for the decreases in the element in the material, the analysis of the elemental composition in the corroded electrode is shown in Table 5. As shown in this table, there is a $\mathrm{Cr}_{2} \mathrm{O}_{3}$ compound in AISI 316 with a relatively large percentage. The $\mathrm{Cr}_{2} \mathrm{O}_{3}$ acts as a protective barrier on the metal surface and inhibit its corrosion in the subsequent process [10]. In addition, the $\mathrm{FeO}$ and $\mathrm{NiO}$ compounds indicate the presence of some pits in AISI 316 after corroded. The presence of $1.80 \%$ of the $\mathrm{Au}_{2} \mathrm{O}_{3}$ compound in EDS testing showed an impurity as a result of the preparation process with $\mathrm{Au}$ coated specimen [22]. 
Table 5. Chemical composition of AISI 316 after corroded in $\mathrm{KOH}$ solution.

\begin{tabular}{llrlr}
\hline \multicolumn{1}{r}{ Element } & $(\mathrm{keV})$ & Mass\% & \multicolumn{1}{c}{ Compound } & Mass\% \\
\hline $\mathrm{C} \mathrm{K}$ & 0.277 & 4.69 & $\mathrm{C}$ & 4.69 \\
$\mathrm{O}$ & & 22.77 & & \\
$\mathrm{Cr} \mathrm{K}$ & 5.411 & 13.34 & $\mathrm{Cr}_{2} \mathrm{O}_{3}$ & 19.49 \\
$\mathrm{Fe} \mathrm{K}$ & 6.398 & 51.24 & $\mathrm{FeO}$ & 65.93 \\
$\mathrm{Ni} \mathrm{K}$ & 7.471 & 6.36 & $\mathrm{NiO}$ & 8.09 \\
Au K & 2.121 & 1.60 & $\mathrm{Au}_{2} \mathrm{O}_{3}$ & 1.80 \\
Total & & 100.00 & & 100.00 \\
\hline
\end{tabular}

* The study used ZAF method standard less quantitative analysis using the fitting coefficient of 0.2207 and total oxide of 24.0 .

\section{Analysis of Hybrid Car Engine System}

\section{Fuel consumption}

The fuel consumption analysis of the car engine equipped by water electrolyser was measured by the CVS method. Figure 3 shows the relationship between fuel consumption and engine rotation. A direct correlation between the engine rotation and the fuel consumption in the range of 2000 to $3500 \mathrm{rpm}$ was found. For engine rotation of more than $3500 \mathrm{rpm}$, the fuel consumption is relatively stable. Based on the figure, the smallest fuel consumption occurred when using $0.40 \mathrm{M}$ of $\mathrm{KOH}$. At steady state engine speed condition, fuel consumption of car engine equipped with water electrolyser of $0.40 \mathrm{M}$ of $\mathrm{KOH}$ was around $5877-6236 \mathrm{~kg} / \mathrm{h}$, whereas fuel consumption of car engine that was not equipped with water electrolyser was around $6233-6856 \mathrm{~kg} / \mathrm{h}$. The comparison between the two car engine conditions showed that fuel saving was $6-10 \%$ when using $0.40 \mathrm{M}$ of $\mathrm{KOH}$.

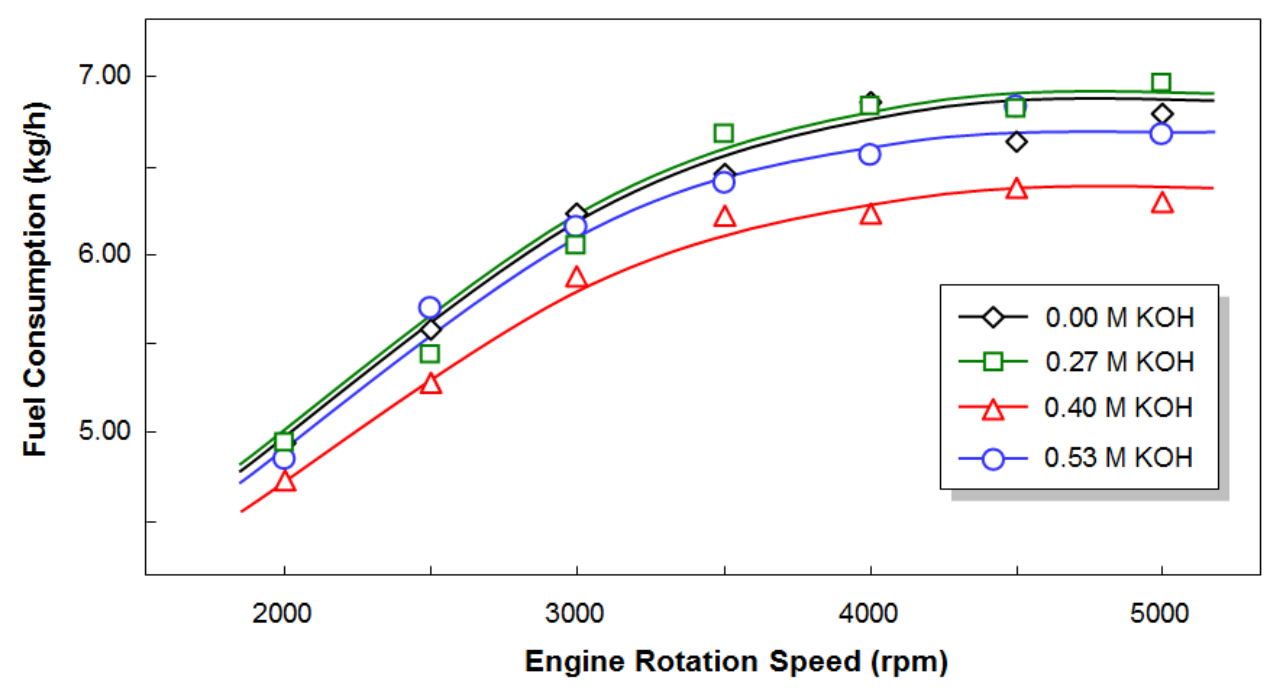

Figure 3. The relationship between fuel consumption and engine rotation.

The fuel savings of car engine equipped by water electrolyser occurred because of the existence of HHO gas in the fuel-air mixture in the combustion chamber. The fuelair mixture (without $\mathrm{HHO}$ ) requires a longer time to ignite before reaching the top dead 
centre (TDC) of the engine. On the other hand, the explosion of gas fumes presses the piston down and out of sequence, so the ignition process makes it less efficient. The pressure of the piston down and out of sequence goes too early and a little in reverse and, therefore, causes a "knocking" noise and produces less power [28].

To enhance the engine power, the octane rating of fuel must be increased. Octane rating indicates how much fuel can be compressed before it ignites. More engine power can be produced by increasing octane rating because combustion will be much closer to TDC. The increase of fuel octane rating can be done by adding HHO to the fuel-air mixture. The new mixture (fuel, air, and $\mathrm{HHO}$ ) can be transformed into mechanical torque without knocking. Indeed, each piston transfers more energy during the combustion cycle, making the combustion more efficient. Certainly, more efficient combustion results in the reduction of fuel consumption [29].

\section{Exhaust gas emissions}

In addition to the impact on fuel savings, the measurements of exhaust gas emission reduction were performed using CVS. The influence of hydrogen generation was analysed to the reduction of exhaust gases, such as $\mathrm{CO}_{2}, \mathrm{CO}$, and $\mathrm{NO}_{\mathrm{x}}$, which are air pollutants and harmful for human health and the environment. Thus, the concentration of these gases must not exceed a certain threshold value.

Table 6 shows the levels of $\mathrm{CO}_{2}, \mathrm{CO}$, and $\mathrm{NO}_{\mathrm{x}}$ in car engine are equipped with and without water electrolyser at an engine speed of $3500 \mathrm{rpm}$. As an example, we took the sample from the uses of $\mathrm{KOH}$ as a model of the electrolyte. We found that car engine equipped with water electrolyser in all $\mathrm{KOH}$ concentrations had relatively low levels of exhaust emissions compared to the car engine without water electrolyser. The reduction in $\mathrm{CO}_{2}, \mathrm{CO}$, and $\mathrm{NO}_{\mathrm{x}}$ is in a range of $7.10-9.10 \%, 1.60-5.60 \%$, and $17.50-28.90 \%$, respectively.

Table 6. Car engine exhaust gas emissions at various $\mathrm{KOH}$ concentrations

\begin{tabular}{lcccc}
\hline & \multicolumn{4}{c}{ KOH concentration added in the electrolyte $(\mathrm{M})$} \\
\cline { 2 - 5 } & 0.00 & 0.27 & 0.40 & 0.53 \\
\hline $\mathrm{CO}_{2}(\%)$ & 5.95 & 5.53 & 5.41 & 6.16 \\
$\mathrm{CO}(\%)$ & 12.4 & 11.7 & 12.2 & 11.9 \\
$\mathrm{NO}_{\mathrm{x}}(\mathrm{ppm})$ & 433 & 357.2 & 339 & 307.8 \\
\hline
\end{tabular}

Slightly different from savings of fuel consumption, the greatest reduction of exhaust gas emissions occurred at various concentrations solution with different types of gases. The lowest levels of $\mathrm{CO}_{2}$ emission occurred in the car engine which was equipped with water electrolyser of $0.40 \mathrm{M}$ of $\mathrm{KOH}$ with a reduction of $9.1 \%$. Meanwhile, the lowest $\mathrm{CO}$ emission occurred in the car engine equipped with water electrolyser of 0.27 $\mathrm{M}$ of $\mathrm{KOH}$ with a reduction of $5.6 \%$. The lowest $\mathrm{NO}_{\mathrm{x}}$ emission occurred in an engine equipped with water electrolyser of $0.53 \mathrm{M} \mathrm{KOH}$ with a reduction of $28.9 \%$. As a comparison, other researchers have shown the suitability of NOx content generated during the coke combustion through unreacted-core model [30]. This study has illustrated the successful application of the unreacted-core model for the NOx emission of coke combustion.

Based on the data of $\mathrm{CO}_{2}, \mathrm{CO}$, and $\mathrm{NO}_{\mathrm{x}}$, the following results are obtained: $\mathrm{CO}_{2}$ had been generated during the burning fuel with oxygen in the combustion chamber. 
Because there is low consumption of fuel, the generated $\mathrm{CO}_{2}$ gases can be reduced. Meanwhile, $\mathrm{CO}$ gas had been produced because the oxygen in the fuel-air-HHO mixture is less than the theoretical value. However, with the additional hydrogen, the generated $\mathrm{CO}$ can be reduced. Meanwhile, $\mathrm{NO}_{\mathrm{x}}$ had been produced because the nitrogen from the air was merged with oxygen at a temperature over $1800^{\circ} \mathrm{C}$. The discussion about these phenomena are in a good agreement with other reports [31]. Other study had investigated that the uses of Jatropha biodiesel and turpentine oil can give a good performance and reduced emissions of the $\mathrm{CO}_{2}, \mathrm{NOx}$, and $\mathrm{CO}$ compared to the pure diesel fuel [17].

\section{CONCLUSION}

We have successfully investigated the surface of AISI 316 as the electrode material for water electrolysis under various potassium hydroxide $(\mathrm{KOH})$ electrolyte concentrations. In the experiment, the electrode was put in the $\mathrm{KOH}$ electrolyte solution with various concentrations (from 0 to $0.53 \mathrm{M}$ ). The electrolysis system was combined with the hybrid car engine system that consumed a combination of hydrogen and gasoline as the fuel source. The results showed that the selection of the cell structure, the electrode material, and the electrolyte solution is an important parameter for maintaining high efficiency of hydrogen generation. These parameters involve the possibility of ion-ion reaction and ion-electrode interaction. The best condition for the production of hydrogen is when using $0.40 \mathrm{M}$ of $\mathrm{KOH}$. The generated gas using the best condition can reduce fuel consumption and exhaust gas emission (e.g. $\mathrm{CO}_{2}, \mathrm{CO}$, and $\mathrm{NO}_{\mathrm{x}}$ ).

\section{ACKNOWLEDGEMENT}

We gratefully acknowledge to Directorate of Research and Community Service, Ministry of Research, Technology, and Higher Education, Republic of Indonesia (RISTEKDIKTI) for financial supporting through the grant of Penelitian Terapan Unggulan Perguruan Tinggi and Penelitian Unggulan Strategis Nasional.

\section{REFERENCES}

[1] Zeng K, Zhang D. Recent progress in alkaline water electrolysis for hydrogen production and applications. Progress in Energy and Combustion Science 2010; 36(3): 307-326.

[2] Siracusano S, Di Blasi A, Baglio V, Brunaccini G, Briguglio N, Stassi A, Ornelas $\mathrm{R}$, Trifoni E, Antonucci V, Aricò A. Optimization of components and assembling in a PEM electrolyzer stack. International Journal of Hydrogen Energy 2011; 36(5): 3333-3339.

[3] Coutanceau C, Baranton S. Electrochemical conversion of alcohols for hydrogen production: a short overview. Wiley Interdisciplinary Reviews: Energy and Environment 2016; 5(4): 388-400.

[4] Nagai N, Takeuchi M, Kimura T, Oka T. Existence of optimum space between electrodes on hydrogen production by water electrolysis. International Journal of Hydrogen Energy 2003; 28(1): 35-41.

[5] Savaris I, Torres C, Sheikh A, Weschenfelder F, Schaeffer L, Malfatti C. Porous $\mathrm{Ni}$ Electrodes for Hydrogen Production from Water Electrolysis. Renewable Energy and Power Quality Journal 2013; 1(11): 609-612. 
[6] De Souza RF, Padilha JC, Gonçalves RS, De Souza MO, Rault-Berthelot J. Electrochemical hydrogen production from water electrolysis using ionic liquid as electrolytes: towards the best device. Journal of Power Sources 2007; 164(2): 792-798.

[7] Yilmaz AC, Uludamar E, Aydin K. Effect of hydroxy (HHO) gas addition on performance and exhaust emissions in compression ignition engines. International Journal of Hydrogen Energy 2010; 35(20): 11366-11372.

[8] Hamidah I, Solehudin A, Setiawan A. Effect of variation of kalium hydroxide solution concentration and temperature to the corrosion resistance of AIS 304 and copper alloys in water electrolysis apparatus. ARPN Journal of Engineering and Applied Sciences 2016; 11(2): 972-977.

[9] Hamidah I, Solehudin A, Setiawan A, Hamdani A, Hidayat MAS, Adityawarman F, Khoirunnisa F, Nandiyanto ABD. Corrosion study of AISI 304 on KOH, $\mathrm{NaOH}$, and $\mathrm{NaCl}$ solution as an electrode on electrolysis process. Journal of Engineering Science and Technology 2018; 13(5): 1345-1351.

[10] Freire L, Nóvoa X, Pena G, Vivier V. On the corrosion mechanism of AISI 204Cu stainless steel in chlorinated alkaline media. Corrosion Science (2008); 50(11): 3205-3212.

[11] Edrah S, Hasan S. Studies on thiourea derivatives as corrosion inhibitor for aluminum in sodium hydroxide Solution. Journal of Applied Sciences Research 2010; 6(8): 1045-1049.

[12] Asmara Y, Kurniawan T. Corrosion prediction for corrosion rate of carbon steel in oil and gas environment: A review. Indonesian Journal of Science and Technology 2018; 3(1): 64-74.

[13] Ganapathy V, Kurniawan T, Ayu HM, Asmara YP, Daud R, Prastomo N, Nandiyanto ABD. Aluminum alloy AA2024 coated with $\mathrm{ZrO} 2$ using a sol-gelassisted dip-coating technique and its corrosion performance. Journal of Engineering Science and Technology 2018; 13(6): 1713-1721.

[14] Kurniawan T, Fauzi FAB, Asmara YP. High-temperature oxidation of Fe-Cr steels in steam condition-A review. Indonesian Journal of Science and Technology 2016; 1(1): 107-114.

[15] Abbaszadeh A, Ghobadian B, Najafi G, Yusaf T. An experimental investigation of the effective parameters on wet washing of biodiesel purification. International Journal of Automotive and Mechanical Engineering 2014; 9(1): 1525-1537.

[16] Asmara Y, Siregar J, Shah L, Tezara C. Experimental investigations on corrosion model of welded 6061 aluminum exposed in $\mathrm{NaCl}$ solution. International Journal of Automotive and Mechanical Engineering 2015; 11: 2600-2607.

[17] Dubey P, Gupta R. Study of the performance and emission characteristics for a dual fuel powered single cylinder diesel engine. International Journal of Automotive and Mechanical Engineering 2016; 13(2): 3373-3388.

[18] Haque MM, Limon SA, Moniruzzaman M, Bepari MM. Corrosion comparison of galvanized steel and aluminum in aqueous environments. International Journal of Automotive and Mechanical Engineering 2014; 9: 1758-1767.

[19] Islami N, Rashid S, Ariffin A, Nuawi M. Stress corrosion damage on austenitic stainless steel in sodium chloride. International Journal of Automotive and Mechanical Engineering 2017; 14(1): 3824-3836.

[20] Moniruzzaman M, Roy S. Effect of $\mathrm{pH}$ on electroless Ni-P coating of conductive and nonconductive materials. International Journal of Automotive and Mechanical Engineering 2011; 4: 481-489. 
[21] Ridha M, Fonna S, Huzni S, Supardi J, Ariffin A. Atmospheric corrosion of structural steels exposed in the 2004 tsunami-affected areas of Aceh. International Journal of Automotive and Mechanical Engineering 2013; 7: 1015-1023.

[22] Loto RT. Pitting corrosion evaluation of austenitic stainless steel type 304 in acid chloride media. Journal of Materials and Environmental Science 2013; 4(4): 448459.

[23] Cardoso M, Amaral S, Martini E. Temperature effect in the corrosion resistance of $\mathrm{Ni}-\mathrm{Fe}-\mathrm{Cr}$ alloy in chloride medium. Corrosion Science 2008; 50(9): 24292436.

[24] Zakeri M, Nakhaie D, Naghizadeh M, Moayed MH. The effect of dichromate ion on the pitting corrosion of AISI 316 stainless steel. Part I: Critical pitting temperature. Corrosion Science 2015; 93: 234-241.

[25] Ernst P, Newman R. Pit growth studies in stainless steel foils. I. Introduction and pit growth kinetics. Corrosion Science 2002; 44(5): 927-941.

[26] Metikoš-Huković M, Babić R, Grubač Z, Petrović Ž, Lajçi N. High corrosion resistance of austenitic stainless steel alloyed with nitrogen in an acid solution. Corrosion Science 2011; 53(6): 2176-2183.

[27] Rokosz K, Hryniewicz T, Raaen S, Valiček J. SEM/EDX, XPS, corrosion and surface roughness characterization of AISI 316L SS after electrochemical treatment in concentrated HNO3. Tehnički Vjesnik 2015; 22(1): 125-131.

[28] Al-Rousan AA. Reduction of fuel consumption in gasoline engines by introducing HHO gas into intake manifold. International Journal of Hydrogen Energy 2010; 35(23): 12930-12935.

[29] Musmar SeA, Al-Rousan AA. Effect of HHO gas on combustion emissions in gasoline engines. fuel 2011; 90(10): 3066-3070.

[30] Hou C, Wu S, Zhang G, Su B, Que Z. Unreacted-core model applied on the NOx emission of coke combustion. Energy Sources, Part A: Recovery, Utilization, and Environmental Effects 2018; 40(4): 388-393.

[31] Saravanan N, Nagarajan G. Performance and emission studies on port injection of hydrogen with varied flow rates with Diesel as an ignition source. Applied Energy 2010; 87(7): 2218-2229. 